\title{
Euplectrus furnius parasitizing Spodoptera frugiperda in maize in Brazil
}

\author{
Euplectrus furnius parasitando Spodoptera frugiperda em milho no Brasil
}

\author{
Vinícius Soares Sturza ${ }^{\mathrm{I}}$ Sônia Thereza Bastos Dequech ${ }^{\mathrm{II}}$ Marcelo Teixeira Tavares ${ }^{\mathrm{III}}$ \\ Candice Guths ${ }^{\text {II }}$ Michel Pires WalkerII Anderson Bolzan ${ }^{\text {II }}$
}

\section{ABSTRACT}

Brazil is among the world's biggest maize producers and fall armyworm, Spodoptera frugiperda (Smith) (Lepidoptera: Noctuidae), is the main insect pest on this crop in the country. Despite the importance of its natural enemies, there still is a lack of information about parasitoids species that attack this insectpest, such as larval parasitoids. This research reports Euplectrus furnius Walker (Hymenoptera: Eulophidae) parasitizing $\boldsymbol{S}$. fugiperda larvae on maize crop in Brazil.
\end{abstract}

- NOTE -
Key words: Larval parasitoid, fall armyworm, Zea mays $L$.

\section{RESUMO}

O Brasil está entre os maiores produtores de milho do mundo e a lagarta-do-cartucho, Spodoptera frugiperda (Smith) (Lepidoptera: Noctuidae) é o principal inseto-praga nessa cultura no país. Apesar da importância de seus inimigos naturais, ainda existe uma falta de informação sobre as espécies de parasitoides que atacam esse inseto-praga, tais como os parasitoides larvais. Este trabalho relata Euplectrus furnius Walker (Hymenoptera: Eulophidae) parasitando larvas de S. frugiperda em milho no Brasil.

Palavras-chave: Parasitoide larval, Lagarta-do-cartucho, Zea mays $L$.

Brazil is the world's third biggest producer of maize (FAO, 2011) and fall armyworm, Spodoptera frugiperda (Smith) (Lepidoptera: Noctuidae) is its main insect pest (FIGUEIREDO et al., 2006). Regardless the number of natural enemies associated to this pest in maize and other different field crops (MOLINA-
OCHOA et al., 2003), there still is necessity of known more about natural enemies of fall armyworm due to their important role. In the recent years, efforts have been made to know these parasitoids and some results are presented here about it.

From January $22^{\text {nd }}$ to February $22^{\text {nd }}$ of 2011, during summer in Brazil, fourteen evaluations in maize plants (from V1 to V10 stages) were made in a maize crop of 0.12 ha area, 30F53 hybrid, located at an experimental area of "Universidade Federal de Santa Maria” (2943’S, 5343’W, 95 MASL ), in the State of Rio Grande do Sul, in the municipality of Santa Maria, Brazil. On each evaluation 80 plants were checked looking for $\boldsymbol{S}$. frugiperda larvae which have been collected. A total of 1120 plants were evaluated and 1322 S. frugiperda larvae collected. Afterwards, larvae were placed in $100 \mathrm{ml}$ plastic cups with artificial diet (BURTON \& PERKINS, 1972) and individually kept under controlled environmental conditions (temperature $25 \pm 1^{\circ} \mathrm{C}$, relative humidity $60 \pm 10 \%$ and photophase 12 hours) until $S$. frugiperda adults or parasitoids emerged. Then parasitoids were kept in $70 \%$ alcohol and identified. Identification was provided by Dr. Marcelo Teixeira Tavares and Vouchers are deposited at Entomological Collection of "Universidade Federal do Espírito Santo".

Four larvae were found parasitized by Euplectrus furnius Walker (Hymenoptera: Eulophidae), two of them collected on February $5^{\text {th }}$ and

\footnotetext{
'Programa de Pós-graduação em Agronomia, Universidade Federal de Santa Maria (UFSM), 97105-900, Santa Maria, RS, Brasil. E-mail: vsturza27@yahoo.com.br. Autor para correspondência.

"IfSM, Santa Maria, RS, Brasil.

IIIDepartamento de Ciências Biológicas, Universidade Federal do Espírito Santo (UFES), Vitória, ES, Brasil. 
other two on February $8^{\text {th }}$. First, second and third instar fall armyworm larvae were parasitized and parasitism rate was $0.3 \%$. The number of parasitoids per larva ranged from one (first instar larvae) to eight (third instar larvae). From each two second instar larvae, five parasitoids emerged, totaling 19 obtained parasitoids.

Parasitoids of genus Euplectrus are widely distributed in the world and known as gregarious ectoparasitoids that frequently develop on many different hosts, including species of Lepidoptera (PUTTLER et al., 1980; COUDRON \& PUTTLER, 1988; JONES \& SANDS, 1999; MURÚA et al., 2004). None of the parasitized larvae reached pupae stage (later parasitoids emerged from third instar at most) and neither adapted ovipositor were verified on females, which indicates that $\boldsymbol{E}$. furnius is possibly a koinobiont (CIRELLI \& PENTEADO-DIAS, 2003).

Euplectrus furnius was previously described parasitizing $\boldsymbol{S}$. frugiperda in Puerto Rico, in rice crops, causing $3.6 \%$ mortality of second and third instar larvae collected (PANTOJA \& FUX, 1992). In South America it was mentioned in Argentina, where five Euplectrus species have been documented so far (VIRLA et al., 1999, MURÚA et al., 2004). In Brazil it was first cited by DE SANTIS \& FIDALGO (1994), but no host, location nor crop were mentioned and only Euplectrus plathypenae Howard (COSTA LIMA, 1962) and Euplectrus ronnai (Brethes) (DE SANTIS, 1980) are recorded parasitizing $\boldsymbol{S}$. frugiperda on maize. This is the first report of $\boldsymbol{E}$. furnius parasitizing $\boldsymbol{S}$. frugiperda larvae on maize in Brazil.

Despite small parasitism rate (0.3\%), 19 adults were obtained from four parasitized larvae. It was observed that the larger the larvae, greater was the number of parasitoids per host obtained. In Brazil 46 different $\boldsymbol{S}$. frugiperda larval parasitoids are known, 45 compiled by MOLINA-OCHOA et al. (2003) and more recently another described by FIGUEIREDO et al. (2006), but most of Hymenoptera larval parasitoid species are not gregarious.

Euplectrus spp. oviposition might reach more than 10 eggs per host (COUDRON \& PUTTLER, 1988) and some species are considered valuable for biological control due to its reproductive potential (JONES \& SANDS, 1999). Four species were already released worldwide on classical biological control programs, all performed against species of Lepidoptera, which one came from South America, Euplectrus puttleri Gordh which was introduced in EUA, in 1975, against Anticarsia gemmatalis (Hübner) (Lepidoptera: Noctuidae), from Colômbia (PUTTLER et al., 1980; MUNIAPPAN et al., 2004).
This record suggests that further studies such as field evaluations in other maize producer regions and laboratory rearing techniques might reveal $\boldsymbol{E}$. furnius potential for using on integrated pest management strategies for $\boldsymbol{S}$. frugiperda on maize crops in Brazil, especially based on its reproductive potential as larval parasitoid.

\section{ACKNOWLEDGMENTS}

The authors thank to Coordenação deAperfeiçoamento de Pessoal de Nível Superior (CAPES) and to Conselho Nacional de Desenvolvimento Científico e Tecnológico (CNPQ).

\section{REFERENCES}

BURTON, R.L; PERKINS, W.D. WSB, a new laboratory diet for the corn earworm and the fall armyworm. Journal of Economic Entomology, v.65, n.2, p.385-386, 1972.

CIRELLI, K.R.N.; PENTEADO-DIAS, A.M. Fenologia dos Braconidae (Hymenoptera, Ichneumonoidea) da área de proteção ambiental (APA) de Descalvado, SP. Revista Brasileira de Entomologia, v.47, n.1, p.99-105, 2003. Available from: <http:// www.scielo.br/pdf/rbent/v47n1/16468.pdf >. Accessed: 30 Mar. 2013. doi: 10.1590/S0085-56262003000100015.

COSTA LIMA, A. Insetos do Brasil XII. Himenópteros, $2^{\text {a }}$ parte (Serie Didática No . 14). Rio de Janeiro: Universidade Rural, Escola Nacional de Agricultura, 1962. 393p. Available from: <http:// www.ufrrj.br/institutos/ib/ento/tomo12.pdf >. Accessed: Apr. 30, 2011.

COUDRON, T.A.; PUTTLER, B. Response of natural and factitious hosts to the ectoparasite Euplectrus plathypenae (Hymenoptera: Eulophidae). Annals of Entomological Society of America, v.81, n.6, p.931-937, 1988. Available from: <http:// digitalcommons.unl.edu/cgi/viewcontent.cgi?article=1099\&conte xt=entomologyother>. Accessed: Apr. 30, 2011.

DE SANTIS, L. Nueva sinonimia, nueva combinación y nuevas citas de Himenopteros Calcidoideos para la República Argentina. Neotrópica, v.26, n.76, p.153-154, 1980.

DE SANTIS, L.; FIDALGO, P. Catalogo de Himenopteros Calcidoideos. Serie de la Academia Nacional de Agronomia y Veterinaria, v.13, p.73, 1994.

FAO. Faostat, Crops. 2011. Available from: <http://faostat.fao. org/site/339/default.aspx>. Acessed: Jan. 30, 2013.

FIGUEIREDO, M.L.C et al. Exasticolus fuscicornis em lagartas de Spodoptera frugiperda. Pesquisa Agropecuária Brasileira, v.41, n.8, p.1321-1323, 2006. Available from: $<$ http://www.scielo.br/scielo.php?script=sci_arttext\&pid=S0100204X2006000800016\&lang=pt $>$. Accessed: Apr. 30, 2011. doi: 10.1590/S0100-204X2006000800016.

JONES, P.; SANDS D.P.A. Euplectrus melanocephalus Girault (Hymenoptera: Eulophidae), an ectoparasitoid of larvae fruit-piercing moths (Lepidoptera: Noctuidae: Catocalinae) from northern Queensland. Australian Journal of Entomology, v.38, p.377381, 1999. 
MOLINA-OCHOA, J. et al. Parasitoids and parasites of Spodoptera frugiperda (Lepidoptera: Noctuidae) in the americas and caribbean basin: an inventory. Florida Entomologist, v.86, n.3, p.254-289, 2003. Available from: <http://journals.fcla.edu/ flaent/article/view/75206/72864>. Accessed: Apr. 30, 2011. doi: 10.1653/0015-4040(2003)086[0254:PAPOSF]2.0.CO;2.

MURÚA, M.G. et al. Natural distribution of parasitoids of larvae of the fall armyworm, Spodoptera frugiperda, in Argentina. Journal of Insect Science, v.9, n.20, p. 1-17, 2009. Available from: <http://www.insectscience.org/9.20/i1536-2442-9-20.pdf>. Accessed: Mar. 30, 2013.

MUNIAPPAN, R. et al. Biology, rearing and field release on Guam of Euplectrus maternus, a parasitoid of the fruit-piercing moth, Eudocima fullonia. BioControl, v.49, n.5, p.537-551, 2004. Available from: <http://www.wptrc.org/userfiles/file/
BioControl-2004.pdf>. Accessed: Mar. 30, 2013. doi: 10.1023/B: BICO.0000036439.74117.2f.

PANTOJA, A.; FUX, J.R. Prevalence of biotic control agents in the fall armyworm Spodoptera frugiperda (J.E. Smith) (Lepidoptera: Noctuidae). Folia Entomológica Mexicana, v.84, p.79-84, 1992. Available from: <http://www.cabdirect.org/ abstracts/19951103482.html>. Accessed: Mar. 30, 2013.

PUTTLER, B. et al. Bionomics of Euplectrus puttleri Gordh, new species, an introduced parasite of the velvetbean caterpillar, Anticarsia gemmatalis from South America. Annals of the Entomological Society of America, v.73, n.1, p.28-35, 1980.

VIRLA, E.G et al. El complejo de los parasitoides del "gusano cogollero" del maíz, Spodoptera frugiperda, em la República Argentina (Insecta: Lepidoptera). Neotrópica, v.45, n.113/114, p.3-12, 1999. 